\title{
Duodenogastric reflux: A cause of gastric mucosal hyperaemia and symptoms after operations for peptic ulceration ${ }^{1}$
}

\author{
M. R. B. KEIGHLEY, P. ASQUITH, AND J. ALEXANDER-WILliams
}

From the General Hospital, Birmingham

SUMMARY This study has investigated the possible association between duodenogastric reflux, gastritis, and symptoms in 35 patients with or without dyspepsia one to 15 years after gastric surgery. Five patients were excluded because of biliary disease, hiatus hernia, or recurrent ulceration. The remaining 30 were assessed by a symptomatic score, measurement of bilirubin and sodium concentrations in samples of fasting gastric juice, endoscopy, gastric biopsy, and the presence of radiological reflux. In 15 patients with a symptom score of less than the median, gastric bilirubin levels were less than $1 \mathrm{mg} / 100 \mathrm{ml}$ in $80 \%$; severe endoscopic changes were seen in only one patient and reflux was not observed. In contrast, in patients with a symptom score in excess of the median fluoroscopic and biochemical reflux was seen in 69 and $80 \%$ respectively and severe mucosal hyperaemia in half. There was a significant correlation between symptoms, gastric hyperaemia, and duodenal reflux $(\mathrm{P}<0.02)$.

After gastric operations there are a number of patients with continued dyspepsia in whom there is no evidence of recurrent peptic ulceration. Although a proportion of these individuals have biliary disease or gastrooesophageal reflux there are a substantial number who do not. In many of the latter, there is endoscopic evidence of gastric mucosal hyperaemia associated with the presence of bile in the stomach and it has been suggested that gastritis associated with duodenal reflux is a cause of their symptoms (DuPlessis, 1962).

Because the results of further gastric surgery in patients who do not have a recurrent ulcer are particularly disappointing (Halpern, Hirschowitz, and Moody, 1973) it is important to establish the cause of continued dyspepsia. It could be argued that one of the reasons for the poor results of re-operating on these patients is that symptoms are related to duodenal reflux. However, it is also possible that regurgitation of bile-stained juice and gastric mucosal hyperaemia are coincidental findings, unrelated to the presence of symptoms. In order to investigate this problem, an attempt has been made to examine the relationship between duodenogastric

${ }^{1}$ This work was presented in part at the spring meeting of the British Society of Gastroenterology, Nottingham, 1974.

Reprint requests to: Mr J. Alexander-Williams.

Received for publication 26 September 1974. reflux, gastritis, and dyspepsia in 35 subjects seen one to 15 years after ulcer surgery.

\section{Patients and Methods}

The clinical material for this study was provided from two sources. There were 17 patients who were referred because of recurrent dyspepsia after previous gastric surgery and 18 who had replied to a postal questionnaire. The latter were selected because of their willingness to attend hospital for investigation and because analysis of their replies showed that they had no complaints. A preliminary barium meal and cholecystogram was performed on all patients. Following this, three individuals were excluded because of gallstones or hiatus hernia whilst two more were subsequently excluded because of endoscopic evidence of recurrent ulceration. Apart from one patient in the group replying to the postal questionnaire with a hiatus hernia, all of the other patients who were excluded were those referred with postoperative dyspepsia. Of the remaining 30 patients, 17 were those who had volunteered for study and there were 13 who complained of postoperative symptoms. These subjects formed the basis of further study. There were 25 male and five female subjects, whose ages ranged from 24 to 64 years with a mean of 42 years. The following operations had been performed: truncal vagotomy 
and pyloroplasty (14), Billroth I partial gastrectomy (6), proximal gastric vagotomy (4), selective vagotomy with or without pyloroplasty (2), Polya gastrectomy (1), pyloroplasty (1), and two patients who had undergone more than one operation.

The following parameters were measured during this study.

\section{SYMPTOMS}

Eight symptoms (fig 1) were chosen for analysis because previous studies had listed them as being common in patients with duodeno-gastric reflux (Kilby, 1970a; Johnson, 1972). The patients were given a specific questionnaire, on which they were asked to list the presence and indicate the severity of these symptoms. After the validity of the replies had been checked by interview, a symptomatic score was calculated by the sum of the score of each symptom. To correlate the various measurements made in this study with the degree of dyspepsia patients were divided into two groups of equal size. For this purpose the median point on the distribution curve of the symptom score was used (Haber and Runyon, 1969). Patients with a score of less than the median were known as group $\mathbf{A}$ and those above as group B (fig 2).

\section{GASTRIC ANALYSIS}

Following an overnight fast, a number 12 Salem sump tube (external diameter $0.3 \mathrm{~cm}$ ) was passed into the stomach. With the patient lying on the left side, the tip of the tube was positioned under fluoroscopic

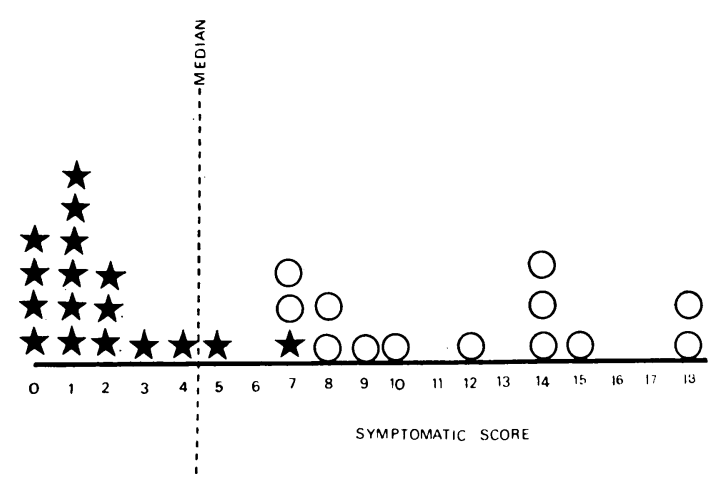

Fig 2 Distribution of the symptomatic score in patients who volunteered for study and those who were investigated because of symptoms. Star = a patient volunteering for study; open circle = a patient referred for investigation of postoperative dyspepsia

control just to the left of the vertebral bodies. Four 10-minute samples of gastric fluid were then aspirated by continual suction for measurement of sodium and bilirubin concentration (method of Northam and Banwell, 1966). To avoid a change in colour due to the conversion of bilirubin to biliverdin at low $\mathrm{pH}$, between the time of collection and bilirubin measurement, $0.5 \mathrm{ml}$ of gastric aspirate was added to $4 \mathrm{ml}$ of bicarbonate buffer ( $\mathrm{pH} \mathrm{8.4)}$ immediately after collection. The greatest concentration of bilirubin in the four gastric samples was known as the 'maximum bilirubin concentration'. The tube was then advanced into the duodenum for

QUESTIONNAIRE

Since your last stomach operation have you ever suffered from any of the following 8 complaints and if so how often or how severely have you done so?

Please tick in the appropriate space for the correct answer and also please write your answer to the question in words in the comment column

COMPLAINT
A. Pain in the upper abdomen after meals
B. Pain behind the breastbone (heartburn)
C. Feeling sick (nausea)
D. Vomiting green or yellow fluid
E. Regurgitation of bitter fluid into the mouth without actually vomiting
F. Upset by fatty food
G. Feeling uncomfortably full after a normal sized meal
H. Repeated belching

\begin{tabular}{|c|c|c|l|l|}
\hline Never & $\begin{array}{c}\text { Mild or only } \\
\text { occasionally }\end{array}$ & $\begin{array}{c}\text { Moderately often } \\
\text { or moderately } \\
\text { severe } \\
2\end{array}$ & $\begin{array}{l}\text { Very often } \\
\text { or very } \\
\text { severe } \\
3\end{array}$ & \multicolumn{1}{|c|}{ COMMENT } \\
\hline & 1 & $\checkmark$ & & $\begin{array}{l}\text { Once or twice a } \\
\text { month }\end{array}$ \\
\hline & & $\checkmark$ & & Two or three times \\
\hline & & $\checkmark$ & & Mild \\
\hline & $\checkmark$ & & & $\begin{array}{l}\text { No trouble with } \\
\text { fatty food }\end{array}$ \\
\hline & & & & Occasionally \\
\hline & $\checkmark$ & & & Occasionally \\
\hline
\end{tabular}

Fig An example of a completed questionnaire in a patient who was given a symptomatic score of 10 
the collection of a single 10-minute sample. The median value for the maximum bilirubin concentration was also used to divide patients into two equal populations. This concentration was $1.0 \mathrm{mg} / 100 \mathrm{ml}$.

\section{RADIOLOGICAL STUDY}

Duodenal reflux was assessed fluoroscopically immediately after obtaining the gastric samples by a modification of the technique described by Capper, Airth, and Kilby (1966). With the patient in the supine position $15 \mathrm{ml}$ of a dilute barium suspension (1 part Micropaque mixed with 2 parts $0.9 \% \mathrm{NaCl}$ ) was introduced slowly down the tube into the duodenum. The gastric tube was then gently withdrawn into the stomach. The duodenogastric segment was observed continuously on the image intensifier for three minutes and then intermittently for a further five minutes. The number of duodenal contractions seen in the first minute of continuous screening were counted. Reflux was recorded if duodenogastric ejection was seen or if the gastric mucosa became coated with barium. The radiological assessment of reflux was considered unsatisfactory in two patients, one due to poor definition because of obesity and the other where there was difficulty in cannulating the duodenum. There were two others who were unsuitable for this test because of a gastrojejunal anastomosis.

\section{ENDOSCOPY}

Endoscopy was performed on 25 patients by one of us (P.A.) without prior knowledge of the patients' symptoms using the end-viewing Olympus GIF type D gastrointestinal fibrescope. The appearance of the gastric mucosa was classified as normal or as showing moderate or severe changes on the basis of the degree and extent of mucosal hyperaemia.

\section{GASTRIC BIOPSY}

At least three biopsies were taken $5 \mathrm{~cm}$ proximal to the stoma or pyloroplasty. The biopsies were sectioned and classified without knowledge of the patient's name as showing mild, moderate, or severe changes according to the extent and severity of the chronic inflammatory cell infiltrate. The presence of acute inflammatory cells in the superficial layers was also recorded as marked, minimal, or absent. Of those who were endoscoped ( 25 patients), material suitable for satisfactory histological grading was obtained in only 18 cases.

\section{Results}

The maximum bilirubin concentration of fasting gastric juice was greater than $1 \mathrm{mg} / 100 \mathrm{ml}$ in only three of the 15 patients $(20 \%)$ from group A. In contrast, there were 12 patients in group $B$ in whom the maximum bilirubin concentration was greater than $1 \mathrm{mg} / 100 \mathrm{ml}(80 \%)$ and in five of these this was in excess of $4 \mathrm{mg} / 100 \mathrm{ml}$ (table I). There was a significant correlation between the number of patients in group $B$ and those with a maximum bilirubin concentration greater than the median $(\mathrm{P}<0.01)$.

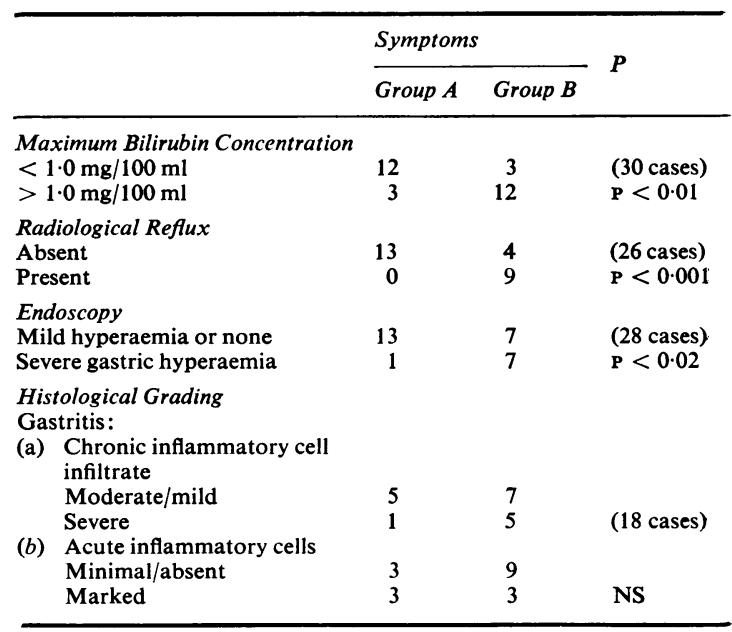

Table I Relationship between symptoms, bilirubin concentrations, radiological reflux, endoscopy, and gastroscopic biopsy

Radiological reflux was not observed in patients from group A but was seen in nine of 13 patients $(69 \%)$ studied from group B $(\mathrm{P}<0.001)$. The appearance of severe mucosal hyperaemia was observed endoscopically in only one patient in group $\mathrm{A}$ but in $50 \%$ of the remainder $(\mathrm{P}<0.02)$. However, there was no correlation between symptoms and histological grading either for the degree of chronic inflammatory cell infiltrate or for the presence of superficial acute inflammatory cells (table I). Although gastritis was more common in patients with reflux and gastric hyperaemia, because of the small numbers in this study these results failed to reach statistical significance (table II). Sodium and bilirubin concentrations were measured in gastric juice to determine whether there was a relationship between the two sets of values. The results show that there was a correlation between these two variables in individual samples of gastric fluid $(\mathrm{P}<0.05)$ (table III).

When the relationship between the maximum bilirubin concentration in gastric juice and the radiological demonstration of reflux was analysed, we were able to demonstrate a highly significant correlation $(\mathrm{P}<0.001)$. The demonstration of radio- 


\begin{tabular}{|c|c|c|}
\hline & \multicolumn{2}{|l|}{ Biopsies } \\
\hline & $\begin{array}{l}\text { Mild or Moderate } \\
\text { Gastritis }\end{array}$ & Severe Gastritis \\
\hline $\begin{array}{l}\text { Maximum Bilirubin Concentration } \\
<1 \mathrm{mg} / 100 \mathrm{ml} \\
>1 \mathrm{mg} / 100 \mathrm{ml}\end{array}$ & $\begin{array}{l}7 \\
3\end{array}$ & $\begin{array}{l}2 \text { (18 patients) } \\
6 \text { NS }\end{array}$ \\
\hline $\begin{array}{l}\text { Radiological Reflux } \\
\text { None } \\
\text { Present }\end{array}$ & $\begin{array}{l}5 \\
5\end{array}$ & $\begin{array}{l}2 \text { (15 patients) } \\
3 \text { NS }\end{array}$ \\
\hline $\begin{array}{l}\text { Endoscopy } \\
\text { Mild hyperaemia or none } \\
\text { Severe gastric hyperaemia }\end{array}$ & $\begin{array}{l}8 \\
4\end{array}$ & $\begin{array}{l}2 \text { (18 patients) } \\
4 \text { NS }\end{array}$ \\
\hline
\end{tabular}

Table II Relationship between degree of chronic inflammatory cell infiltrate, maximum bilirubin concentrations, radiological reflux, and endoscopic appearances

\begin{tabular}{clc}
\hline Bilirubin Concentration & \multicolumn{2}{l}{ Sodium Concentration } \\
\cline { 2 - 3 } & $\begin{array}{l}\text { Na<90 } \\
\text { m-equiv/l }\end{array}$ & $\begin{array}{l}\text { Na }>90 \\
\text { m-equiv/l }\end{array}$ \\
\hline$<1.0 \mathrm{mg} / 100 \mathrm{ml}$ & 38 & 4 \\
$>1.0 \mathrm{mg} / 100 \mathrm{ml}$ & 12 & 15 \\
$\mathrm{P}<0.05$ & & \\
\hline
\end{tabular}

Table III Relationship between individual sodium and bilirubin concentrations in fasting gastric aspirate

logical reflux was also associated with severe changes on endoscopy ( $P<0.01)$ (table IV). The duodenum appeared to be nearly twice as active in patients with radiological reflux than in those without, the number of contractions seen per minute being $12.9 \pm 4 \cdot 1$ (ISD) and 6.4 \pm 3.9 (ISD) respectively.

\section{Discussion}

There is evidence that duodenal fluid entering the stomach may be an important cause of localized gastritis and even peptic ulceration (Lawson, 1964; Rhodes, Barnado, Philips, Randolph, Rovelstad, and Hofmann, 1969). Duodenal reflux is also associated with flatulent dyspepsia and severe symptoms (Johnson, 1972; Kilby, 1970a). In the experimental animal, bile reflux has been shown to have a cytolytic effect on the cells of the gastric

\begin{tabular}{lrlll}
\hline & \multicolumn{2}{c}{ Radiology } & & \\
\cline { 2 - 4 } & No Reflux & Refux & \\
\hline $\begin{array}{l}\text { Maximum Bilirubin Concentration } \\
<1.0 \mathrm{mg} / 100 \mathrm{ml}\end{array}$ & 13 & 0 & \\
$>1.0 \mathrm{mg} / 100 \mathrm{ml}$ & 3 & 9 & $\mathrm{P}<0.001$ \\
$\begin{array}{l}\text { Endoscopy } \\
\text { Mild hyperaemia or none }\end{array}$ & 14 & 4 & \\
Severe gastric hyperaemia & 0 & 5 & $\mathrm{P}<0.01$ \\
\hline
\end{tabular}

Table IV Relationship between radiological reflux, bilirubin concentration, and endoscopic appearances mucosa (Grant, Grossman, Wang, and Ivy, 1951). Also, bile salts can destroy the normal mucosal barrier allowing the transmural flux of hydrogen ions into the cells with a loss of sodium into the gastric lumen (Davenport, 1968; Chapman, Rudick, Dyck, Werther, and Janowitz, 1969). For this reason the sodium concentration of gastric juice has been used as an indicator of reflux (Fiddian-Green, Russell, and Hobsley, 1972). The effect of reflux on the gastric mucosa appears to be even greater when bile and pancreatic juice enter the stomach (Lawson, 1964) particularly where there is normal or excessive gastric acid secretion (Kilby, 1970a).

Very much less is known about the importance of intragastric bile and pancreatic juice as a cause of symptoms and gastritis after operation. It has been shown that the normal pylorus prevents the reflux of duodenal contents into the stomach (Kilby, 1970a). These observations have also been confirmed by measuring the bile acid concentrations in fasting and postprandial gastric juice in normal subjects (Black, Roberts, and Rhodes, 1971). It has been suggested, therefore, that any operation interfering with this mechanism will predispose to duodenal reflux (DuPlessis, 1960; Kilby, 1970b). Regurgitation of duodenal juice has also been reported as being associated with gastritis and symptoms after gastric surgery (DuPlessis, 1962; Toye and Williams, 1965; Capper, 1967).

Kilby (1970a) studied 30 patients after gastric surgery by the method described by Capper (1966). Using $150 \mathrm{ml}$ of a heavy barium suspension, the pyloroplasty or gastroduodenostomy was invariably found to be incompetent. However, in his method the tube was left in the duodenum during the entire screening period and it is possible that this may have facilitated reflux, particularly in patients studied after operation.

In the present method of investigation a smaller volume of a more physiological barium suspension was used in order that the osmolarity and the bolus effect of the barium should be less likely to have a stimulant effect on duodenal contraction. Withdrawal of the tube into the stomach before assessing reflux was also used in order to avoid an artificial means of invoking duodenal activity. What has been observed therefore is the direction and amplitude of duodenal peristalsis rather than the apparent incompetence of the duodeno-gastric junction. Under the conditions of this study duodenal contents ejected in a retrograde manner were related to symptoms and endoscopic evidence of mucosal hyperaemia.

Although the concentration of bilirubin in the gastric aspirate and the presence of bile seen endoscopically are associated with symptoms, it is by no means clear from this study whether it is bile itself 
or some other substance in the duodenal juice which is responsible for these mucosal changes. Bilirubin was used merely as a marker of duodenal reflux. Alkaline gastritis is probably due to the effect of trypsin and bile salts on the gastric mucosa. All the samples of gastric aspirate in this study had a pH of greater than $2 \cdot 0$. Nevertheless we always immediately added a bicarbonate buffer to the aspirate to ensure the stability of the bilirubin pigment which is known to be unstable at a pH of less than 2.0.

We were not surprised to find a poor correlation between histological evidence of gastritis and the macroscopic appearances of mucosal hyperaemia. This was probably related to the large number of different operations which was responsible for the lack of uniformity in anatomical structure of stoma or pyloroplasty biopsies. The only satisfactory way to compare the histological changes in relation to symptoms and reflux would be to examine gastric biopsies taken within each operation group. The numbers in this study were too small to allow such a comparison. Even if this were possible gastritis has a patchy distribution making comparisons even at specific sites unreliable. What is more, previous studies have also shown a poor correlation between endoscopic appearances and histological changes in patients with gastritis before operation (Morrissey, 1972; Thomas, Hall, and Hislop, 1973).

One further problem is the wide differences between the time of operation and follow up. Nevertheless it is our impression that symptoms often take between one and five years to develop after surgical treatment. For this reason further studies will be necessary in more closely defined operation groups at a specific period of follow up. It is also possible that some of the symptoms which we chose occurred more frequently in patients with duodenal reflux than in others. In order to investigate this point, the number of patients with a maximum bilirubin concentration of greater than $1 \mathrm{mg} / 100 \mathrm{ml}$ was related to each symptom (table V). It can be seen

\begin{tabular}{|c|c|c|c|}
\hline \multirow[t]{2}{*}{ Symptoms } & \multirow{2}{*}{$\begin{array}{l}\text { Total No. of } \\
\text { Patients } \\
\text { Complaining }\end{array}$} & \multicolumn{2}{|c|}{$\begin{array}{l}\text { Those with Maximum } \\
\text { Bilirubin Concentration }\end{array}$} \\
\hline & & $\begin{array}{l}<1 \mathrm{mgl} \\
100 \mathrm{ml}\end{array}$ & $\begin{array}{l}>1 \mathrm{mgl} \\
100 \mathrm{ml}\end{array}$ \\
\hline Bile vomiting & 8 & 1 & 7 \\
\hline Nausea & 14 & 2 & 12 \\
\hline Epigastric pain after meals & 13 & 2 & 11 \\
\hline Bile regurgitation & 13 & 3 & 10 \\
\hline Heartburn & 13 & 3 & 10 \\
\hline Fatty intolerance & 11 & 3 & 8 \\
\hline Abdominal distension & 15 & 5 & 10 \\
\hline Belching & 15 & 6 & 9 \\
\hline
\end{tabular}

Table V Maximum bilirubin concentration in relation to symptom score that the least reliable symptoms were those of excessive belching and abdominal distension. The remainder were all associated with a high incidence of bile-stained gastric juice. Despite these theoretical criticisms there appears to be a close correlation between duodenal reflux and symptoms and it is likely that further gastric surgery other than biliary diversion is likely to aggravate rather than improve symptoms (Pyrtek and Bartus, 1973).

We wish to thank Dr P. W. Dykes for referring a number of patients for this study. We are grateful to Sister Tillotson and the staff of Ward 20 for their cooperation and help and Elizabeth Bradfield for the measurement of bilirubin and sodium concentrations of the gastric juice.

\section{References}

Black, R. B., Roberts, G., and Rhodes, J. (1971). The effect of healing in bile reflux in gastric ulcer. Gut, 12, 552-558.

Capper, W. M. (1967). Factors in the pathogenesis of gastric ulcer. Ann. Roy. Coll. Surg. Engl., 40, 21-35.

Capper, W. M., Airth, G. R., and Kilby, J. O. (1966). A test for pyloric regurgitation. Lancet, 2, 621-622.

Chapman, M. L., Rudick, J., Dyck, W. D., Werther, J. L., and Janowitz, H. D. (1969). Electrolyte movements across the gastric mucosa; the effects of bile on the permeability of antrum and fundus (Abst.). J. clin. Invest., 48, 15a.

Davenport, H. W. (1968). Destruction of the gastric mucosal barrier by detergents and urea. Gastroenterology, 54, 175-181.

DuPlessis, D. J. (1960). Some aspects of the pathogenesis and surgical management of peptic ulcers. S. Afr. med. J., 34, 101-108.

DuPlessis, D. J. (1962). Gastric mucosal changes after operations on the stomach. S. Afr. med. J., 36, 471-478.

Fiddian-Green, R. G., Russell, R. C. G., and Hobsley, M. (1972). Secretin induced pyloric reflux: verification of the mathematical formula for eliminating reflux in gastric aspirate. Brit. J. Surg., 59, 903.

Grant, R., Grossman, M. I., Wang, K. J., and Ivy, A. C. (1951). The cytolytic action of some gastrointestinal secretions and enzymes on the epithelial cells of the gastric and duodenal mucosa. J. Cell. Comp. Physiol., 37, 137-161.

Haber, A., and Runyon, R. P. (1969). General Statistics, p. 74. Addison-Wesley, Reading, Massachusetts.

Halpern, N. B., Hirschowitz, B. L., and Moody, F. G. (1973). Failure to achieve success with remedial gastric surgery. Amer. J. Surg., 125, 108-115.

Johnson, A. G. (1972). Pyloric function and gallstone dyspepsia. Brit. J. Surg., 59, 449-454.

Kilby, J. O. (1970a). Pyloric closure as an anti-reflux mechanism. MS Thesis, London University.

Kilby, J. O. (1970b). Duodenogastric reflux and pyloric surgery. Gastroenterology, 58, 593-595.

Lawson, H. H. (1964). Effect of duodenal contents on the gastric mucosa under experimental conditions. Lancet, 1, 469-472.

Morrissey, J. F. (1972). Gastrointestinal endoscopy. Gastroenterology, 62, 1241-1268.

Northam, B. E., and Banwell, J. G. (1966). Automated analysis in the investigation of pancreatic function. In Technicon International Symposium: Automation in Analytical Chemistry, pp. 215-221. Mediad, White Plains, New York.

Pyrtek, L. J., and Bartus, S. A. (1973). Reflux bile gastritis. Amer. J. Surg., 125, 408-412.

Rhodes, J., Barnado, D. E., Phillips, S. F., Rovelstad, R. A., and Hofmann, A. F. (1969). Increased reflux of bile into the stomach in patients with gastric ulcer. Gastroenterology, 57, 241-252.

Thomas, E., Hall, P., and Hislop, I. G. (1973). Histological changes in the gastric mucosa of chronic gastric ulcer patients treated with carbenoxolone. Gut, 14, 552-554.

Toye, D. K. M., and Williams, J. A. (1965). Post-gastrectomy bile vomiting. Lancet, 2, 524-526. 